\title{
Metabolic Changes in Tumor Microenvironment: How Could They Affect $\gamma \delta$ T Cells Functions?
}

\author{
Anna Maria Corsale ${ }^{1,2,+}$, Marta Di Simone ${ }^{1,2,+}$, Elena Lo Presti ${ }^{3}$, Carmela Picone ${ }^{1,2}$, Francesco Dieli ${ }^{1,2}$ (D) \\ and Serena Meraviglia $1,2, *$ (D)
}

1 Department of Biomedicine, Neurosciences and Advanced Diagnosis, University of Palermo, 90133 Palermo, Italy; annamaria.corsale@unipa.it (A.M.C.); marta.disimone@unipa.it (M.D.S.); carmela.picone@unipa.it (C.P.); francesco.dieli@unipa.it (F.D.)

2 Central Laboratory of Advanced Diagnosis and Biomedical Research (CLADIBIOR), University of Palermo, 90127 Palermo, Italy

3 National Research Council (CNR), Institute for Biomedical Research and Innovation (IRIB), 90146 Palermo, Italy; elena.lopresti@irib.cnr.it

* Correspondence: serena.meraviglia@unipa.it; Tel.: +39-091-655-4097

+ Co-first authors.

check for

updates

Citation: Corsale, A.M.; Di Simone, M.; Lo Presti, E.; Picone, C.; Dieli, F.; Meraviglia, S. Metabolic Changes in Tumor Microenvironment: How Could They Affect $\gamma \delta$ T Cells Functions? Cells 2021, 10, 2896. https://doi.org/10.3390/ cells10112896

Academic Editor: Maria Letizia Taddei

Received: 31 August 2021

Accepted: 21 October 2021

Published: 26 October 2021

Publisher's Note: MDPI stays neutral with regard to jurisdictional claims in published maps and institutional affiliations.

Copyright: (c) 2021 by the authors. Licensee MDPI, Basel, Switzerland. This article is an open access article distributed under the terms and conditions of the Creative Commons Attribution (CC BY) license (https:// creativecommons.org/licenses/by/ $4.0 /)$.

\begin{abstract}
The metabolic changes that occur in tumor microenvironment (TME) can influence not only the biological activity of tumor cells, which become more aggressive and auto sustained, but also the immune response against tumor cells, either producing ineffective responses or polarizing the response toward protumor activity. $\gamma \delta \mathrm{T}$ cells are a subset of T cells characterized by a plasticity that confers them the ability to differentiate towards different cell subsets according to the microenvironment conditions. On this basis, we here review the more recent studies focused on altered tumor metabolism and $\gamma \delta$ T cells, considering their already known antitumor role and the possibility of manipulating their effector functions by in vitro and in vivo approaches. $\gamma \delta \mathrm{T}$ cells, thanks to their unique features, are themselves a valid alternative to overcome the limits associated with the use of conventional $\mathrm{T}$ cells, such as major histocompatibility complex (MHC) restriction, costimulatory signal and specific tumor-associated antigen recognition. Lipids, amino acids, hypoxia, prostaglandins and other metabolic changes inside the tumor microenvironment could reduce the efficacy of this important immune population and polarize $\gamma \delta$ T cells toward IL17 producing cells that play a pro tumoral role. A deeper knowledge of this phenomenon could be helpful to formulate new immunotherapeutic approaches that target tumor metabolisms.
\end{abstract}

Keywords: tumoral metabolism; $\gamma \delta$ T cells; tumor microenvironment

\section{Introduction}

It is well known that metabolic alterations related to cancer development are part of the "hallmarks of cancer" [1]. Cancer cells can modify the surrounding stroma by acidifying the environment [2,3], competing with other healthy cells for nutrients [4,5] and causing oxygen deprivation and reactive oxygen intermediates production due to accelerated metabolism required for tumor proliferation [6].

To date, an increased number of studies focus on the role of tumor cell metabolism [7]. The predominant metabolism program of tumor cells is the so-called "Warburg effect", namely, their preferential use of aerobic glycolysis rather than oxidative phosphorylation (OXPHOS) to generate ATP, even in the presence of oxygen [8,9]. As a result, large glucose consumption implies the accumulation of lactic acid and consequently its release in the extracellular environment. Here, lactate induces the acidification of TME, improving tumor cells aggressiveness and negatively influencing the antitumor immune response [10]. In addition, tumor growth requires additional metabolic processes such as glutaminolysis or increasing lipogenesis. Glutamine metabolism provides amino acids, nucleic acids and 
glutathione, all of them necessary for tumor cell proliferation, thus depriving them of immune cells in the TME and limiting their ability to proliferate.

Moreover, tumor cells synthesize de novo fatty acids and cholesterol for plasma membrane biogenesis. High levels of these lipid metabolites in the TME steer immune cells toward immunosuppressive and anti-inflammatory functions [11]. In particular, cholesterol produced by tumor cells promotes the expression of suppressive immune checkpoints on T cells, causing their exhaustion and dysfunctional state [12]. As already mentioned, these metabolic changes have an influence on the immune response against tumor cells producing ineffective responses [13] or polarizing the response toward protumor activity [14,15] (Figure 1). Generally, immune cells under resting or activated states dictate the engagement of distinct metabolic pathways to proliferate and maintain effector functions. Naive T cells rely on the full oxidation of glucose through OXPHOS and fatty acid oxidation (FAO) to support ATP requests. It is known that upon TCR triggering by peptide antigen MHC, metabolic reprogramming occurs, mediated through the PI3K/Akt/mTOR pathway which increases glycolytic activity in T cells, similar to the "Warburg effect" seen in cancer cells $[16,17]$. Increased aerobic glycolysis, glutamine catabolism and fatty acid synthesis are observed in several subsets of effector T cells, including Th1, Th2, Th17 and cytotoxic CD8 ${ }^{+}$ $\mathrm{T}$ cells and sustain their effector cytokine production and cytotoxic function. In contrast, memory and regulatory $\mathrm{T}$ cells are dependent upon FAO and OXPHOS pathways as naive T cells $[16,17]$.
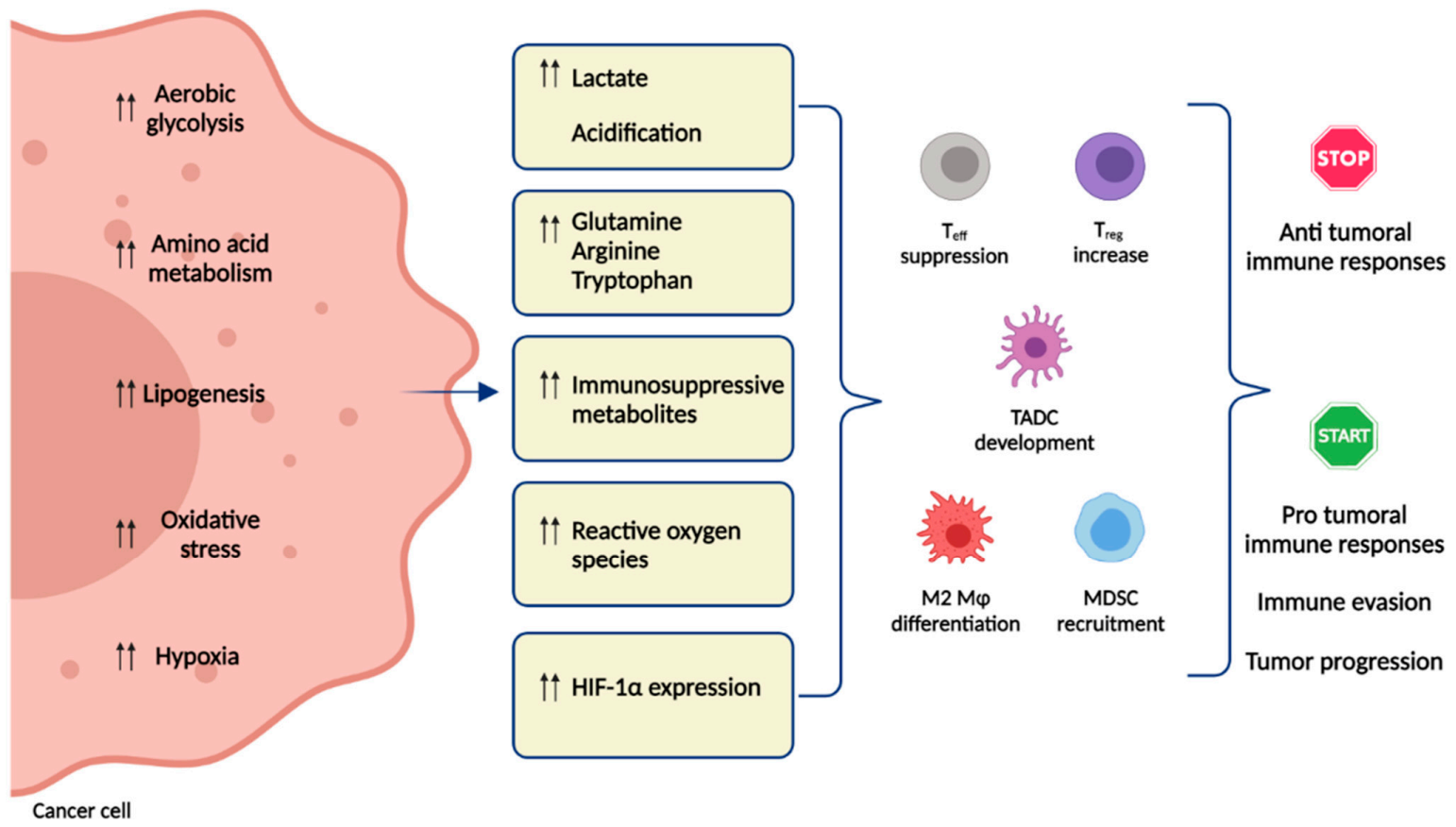

Figure 1. Implications of tumor metabolic reprogramming on immune responses. The immune response is affected by metabolic reprogramming in the TME and is driven by the increased demand for energy sources (glucose) and nutrients (glutamine, arginine, tryptophan) by cancer cells. Tumor-derived metabolites, such as lactate, prostaglandins, kynurenines, fatty acids, adenosine or reactive oxygen species, inhibit $\mathrm{T}_{\text {eff }}$ cell proliferation and cytotoxicity, turning off anti tumoral immune responses. Several immunosuppressive cells are activated or recruited to the TME (e.g., Treg, M2 M $\varphi$, MDSC, TADC), favoring tumor progression. Double arrows indicate the upregulation of metabolic pathways in tumor cells. Abbreviations: $\mathrm{T}_{\text {eff }}$, effector T cells; $\mathrm{T}_{\text {reg, }}$, regulatory T cells; $\mathrm{M} 2 \mathrm{M} \varphi$, activated M2 macrophages; MDSC, myeloid-derived suppressor cells; TADC, tumor-associated dendritic cells.

Although we know more about $\alpha \beta$ T cell metabolism, there is weak knowledge on $\gamma \delta \mathrm{T}$ cells, which are also involved in antitumor immune response. Since the altered metabolism of tumor cells influences the environment in which also $\gamma \delta \mathrm{T}$ cells are recruited, a deeper knowledge of their energy metabolism could be helpful to improve $\gamma \delta \mathrm{T}$ cell-based 
immunotherapies [18-20]. A growing amount of evidence supports the idea that $\gamma \delta \mathrm{T}$ cells are involved in immune responses in the tumor microenvironment [21], although their role is still unclear, given that in different tumors they seem to correlate with positive [22] or negative $[23,24]$ prognostic factors, or even do not correlate at all with patients' outcome. Despite this, $\gamma \delta \mathrm{T}$ cells are considered excellent candidates for cellular immunotherapy against cancer cells as in the most avantgarde immunological approaches (CAR-T) [25] (Figure 2). Table 1 summarizes the main characteristics that make $\gamma \delta \mathrm{T}$ cells good defenders against tumors compared to others T cells $[26,27]$.
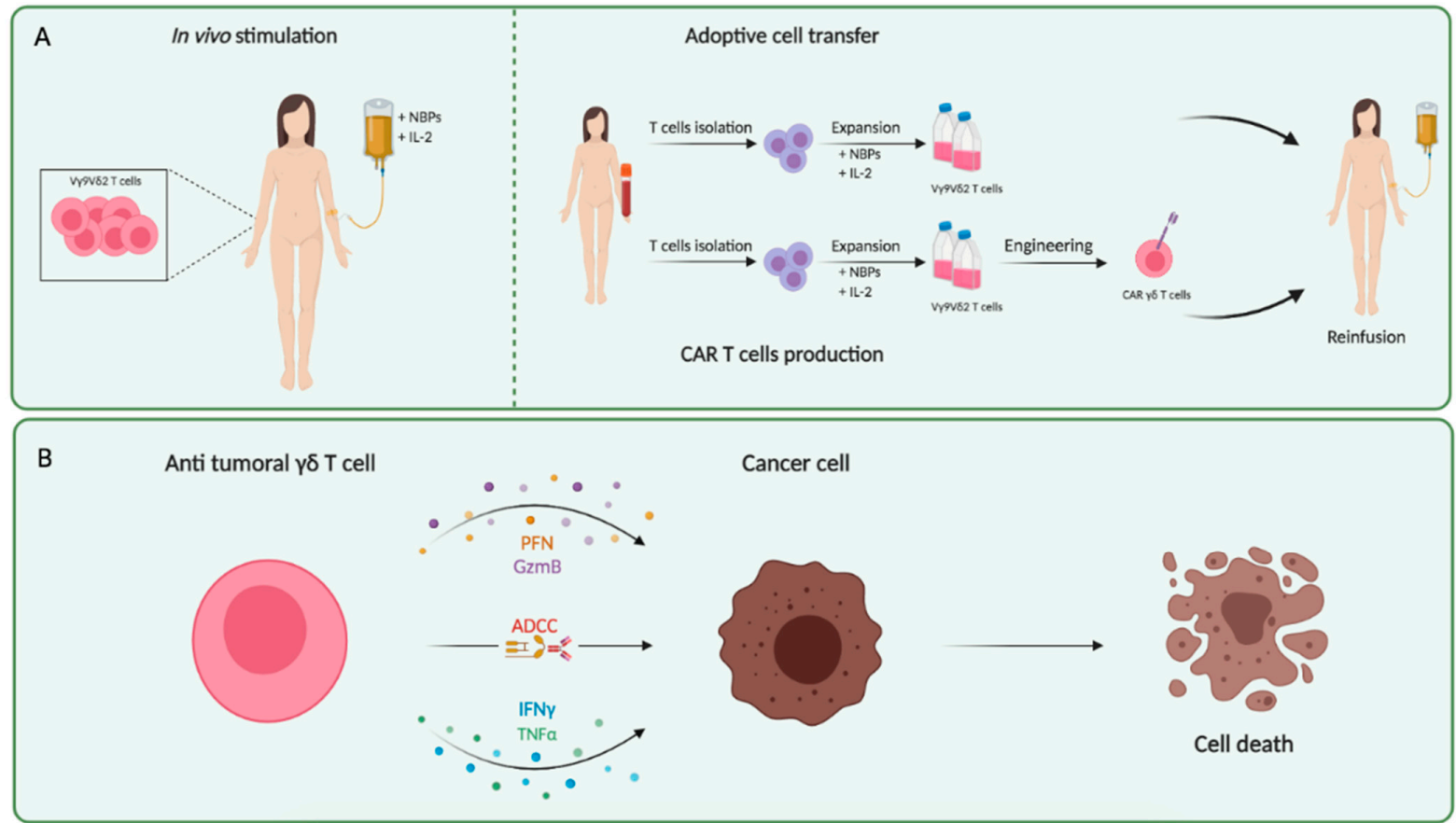

Figure 2. $\gamma \delta$ T cells: clinical use and antitumor activity. (A) Clinical trials based on $\gamma \delta \mathrm{T}$ cells rely on the V $\gamma 9 \mathrm{~V} \delta 2$ subset, taking advantage of two distinct approaches, in vivo and ex vivo. In vivo stimulation involves N-BPs administration, in combination with IL-2, necessary for $\mathrm{V} \gamma 9 \mathrm{~V} \delta 2$ expansion. Adoptive cell transfer (ex vivo approach) requires isolating $\mathrm{T}$ cells from PBMCs and V $\gamma 9 \mathrm{~V} \delta 2$ activation by culture with N-BPs plus IL-2. Then, the expanded V $\gamma 9 \mathrm{~V} \delta 2$ cells are reinfused into patients. Furthermore, to perform CAR-T cell production, $\mathrm{V} \gamma 9 \mathrm{~V} \delta 2$ are expanded as previously and transduced with the specific CAR retrovirus. (B) The cytotoxic mechanisms exerted by $\gamma \delta \mathrm{T}$ cells, triggered upon TCR-dependent antigen recognition, mainly include perforin-granzyme pathway, ADCC, IFN- $\gamma$ and TNF- $\alpha$ production. Abbreviations: N-BPs, nitrogen-containing bisphosphonates; IL-2, interleukine-2; PBMCs, peripheral blood mononuclear cells; CAR, chimeric antigen receptor; TCR, T cell receptor; ADCC, antibody-dependent cell-mediated cytotoxicity.

Table 1. Characteristics that make $\gamma \delta \mathrm{T}$ cells good defenders against tumors compared to others T cells.

\begin{tabular}{ccc}
\hline Features & $\gamma \delta$ T Cells & Other T Cells \\
\hline High frequency & $x$ & $\checkmark$ \\
Recognize and lyse a broad range of tumor cells & $\checkmark$ & $\checkmark$ \\
Lack MHC restriction in antigen recognition & $\checkmark$ & $x$ \\
Require co-stimulatory signals (e.g., CD28) & $x$ & $\checkmark$ \\
Cytotoxic abilities (ADCC) & $\checkmark$ & $x$ \\
In vivo activation using FDA-approved drugs (Zoledronate, IL-2) & $\checkmark$ & $x$ \\
\hline
\end{tabular}

$\gamma \delta \mathrm{T}$ cells are found either in tissues as part of the immune-resident population, or in the peripheral blood, as circulating cells. Tissue-resident $\gamma \delta \mathrm{T}$ cells preferentially express the $V \delta 1$ chain frequently associated with different $V \gamma$ elements. On the other hand, circulating $\gamma \delta \mathrm{T}$ cells preferentially express the $\mathrm{V} \delta 2$ chain paired with the $\mathrm{V} \gamma 9$ chain and this subset, which is referred to as $\mathrm{V} \gamma 9 \mathrm{~V} \delta 2$, accounts for $50 \%$ to $90 \%$ of all $\gamma \delta \mathrm{T}$ cells $[28,29]$. 
Combined expression of differentiation markers such as CD45RA and CCR7 or CD27 allows distinguishing four different cellular types linked to their different functional capacity [30]. Naive cells express both markers and have a high proliferative capacity, shared with the central memory cells, which express only CCR7 or CD27. Instead, the cells that exert the effector and cytotoxic activities are effector memory (double negative) and terminally differentiated $\left(\mathrm{CD} 45 \mathrm{RA}^{+}\right)$, respectively, currently the best candidates for use in immunotherapies [31].

Ex vivo and in vitro studies have described the chameleon-like aspect of $\gamma \delta \mathrm{T}$ cells, which can change their functionality adapting to the microenvironment [32-36]. This aspect has been seen in our study on colorectal cancer [37] and squamous cell carcinoma [38], in which molecules produced by tumor cells or tumor-associated fibroblasts modify their proliferative and functional capacities. The microenvironment heterogeneity can be the bearer of changes that can damage the antitumor functions of $\gamma \delta \mathrm{T}$ cells, as pointed out in a study on breast cancer or hepatocellular carcinoma in which tumor-infiltrating $\gamma \delta \mathrm{T}$ cells correlated with the presence of IL17 and therefore with advanced stages of cancer $[23,24]$.

\section{Metabolic Features of $\gamma \delta$ T Cells}

As previously described, the activation and differentiation of immune cells are correlated to their metabolic profile, which represents a read-out key of functional states [39]. Recently, using SCENITH (Single Cell Metabolism by Profiling Translation Inhibition) protocol [40], Lopes and colleagues explored the distinct metabolic features of mouse $\gamma \delta$ T cell subsets: antitumoral IFN- $\gamma$-producing $\gamma \delta \mathrm{T}$ cells $\left(\gamma \delta^{\mathrm{IFN}}\right.$ cells) and protumoral IL17-producing $\gamma \delta$ T cells ( $\gamma \delta^{17}$ cells) [41].

This flow-cytometry-based method allows analyzing energetic cell metabolism, monitoring changes in protein synthesis through the incorporation of puromycin. Next, with specific metabolic inhibitors, it is possible to estimate glucose and mitochondrial dependence, glycolytic capacity, fatty acid and amino acid oxidation capacity [40].

The authors demonstrated that, during thymic development, $\gamma \delta \mathrm{T}$ cells acquired specific metabolic profiles, preserved in peripheral lymphoid organs and TME of mouse breast and colon cancer models. In the periphery, $\gamma \delta^{17}$ cells showed higher mitochondrial mass and membrane potential compared to $\gamma \delta^{\mathrm{IFN}}$ cells. According to this evidence, whereas antitumoral $\gamma \delta^{\mathrm{IFN}}$ cells showed high glycolytic activity, similarly to NK [42] and CD8 ${ }^{+}$ $\mathrm{T}$ cells [43], $\gamma \delta^{17}$ cells required OXPHOS-based mitochondrial metabolism, like Th17 cells [44].

Furthermore, evaluating mRNA levels of key mitochondrial and glycolysis-associated genes in purified peripheral $\gamma \delta^{17}$ and $\gamma \delta^{\mathrm{IFN}}$ cells, they assessed that this metabolic duality had a transcriptional basis. On the one hand, $\gamma \delta^{17}$ cells were characterized by the presence of Nrf, a regulator of mitochondrial DNA transcription, on the other hand, $\gamma \delta^{\mathrm{IFN}}$ cells expressed Myc, a regulator of glycolysis. Then, evaluating metabolic programs in the thymus, the authors showed that $\gamma \delta$ thymocyte subpopulations followed the same trend seen in the periphery [41].

The following paragraphs will deal with the influence of metabolic intermediates on $\gamma \delta \mathrm{T}$ cells function and how the modulation of tumor metabolism can be exploited to boost the antitumor activity of $\gamma \delta$ T cells for immunotherapy approaches.

\section{Phosphoantigens and Nitrogen-Containing Bisphosphonates}

An efficient anti-tumor response by $\gamma \delta \mathrm{T}$ cells relies on their recognition of tumor antigens. V $\delta 1$ and V $\delta 2$ subsets stand out for their ability to recognize distinct antigens. Although it is still not clear how V $\delta 1$ activation occurs, it is known that they recognize MHC-related molecules, such as MICA, MICB and ULPB, commonly expressed on tumor cells $[45,46]$. Conversely, V $\delta 2$ cells are activated by phosphoantigens (pAgs), a class of small lipidic molecules derived from the mevalonate pathway [47,48], without MHC restriction [49] 
Examples of pAgs are isopentenyl pyrophosphate (IPP), which originates from the endogenous mevalonate (MVA) pathway, and (E)-4-Hydroxy-3-methyl-but-2-enyl pyrophosphate, an intermediate of the non-mevalonate pathway [50,51].

Hyperactive mevalonate metabolism, typical of tumor cells, alerts the immune system. The mevalonate pathway is upregulated in tumor cells, often due to a gain of function mutation of the oncosuppressor p53, which physiologically regulates this pathway [52]. Tumor cells may also undergo dysregulation of the MVA pathway due to losing control of HMG-CoA reductase or its over-expression [53]. All this determines an accumulation of mevalonate metabolites, including IPP, which activates the V $\gamma 9 \mathrm{~V} \delta 2 \mathrm{TCR}$. As recently demonstrated, pAgs activation of $\mathrm{V} \gamma 9 \mathrm{~V} \delta 2 \mathrm{~T}$ cells critically depends on butyrophilin 3A1 and 2A1 [54-58]. IPP-activated $\mathrm{V} \gamma 9 \mathrm{~V} \delta 2 \mathrm{~T}$ cells can proliferate, produce effector cytokines such as IFN- $\gamma$ and TNF- $\alpha$ and display natural killer cell-like cytotoxicity and thus represent a novel target of tumor immunotherapy [59].

Blocking the MVA pathway downstream, and consequently causing the accumulation of metabolites such as IPP, can be obtained using nitrogen-containing bisphosphonates (N-BPs), a type of drug currently used to treat osteoporosis and bone metastasis [60]. N-BPs inhibit farnesyl diphosphate synthase (FPPS), the enzyme that catalyzes the condensation between dimethyl-allyl-pyrophosphate and isopentenyl pyrophosphate to give rise to geranyl pyrophosphate, and the subsequent reaction with a further molecule of isopentenyl pyrophosphate to produce farnesyl pyrophosphate [61].

These data have been confirmed by the study of $\mathrm{Li}$ and colleagues using mevastatin (an IPP-synthesis-inhibiting drug) which reduced V $\gamma 9 \mathrm{~V} \delta 2 \mathrm{~T}$ cells activation, while N-BP inhibition of FPPS promotes their stimulation [62].

Several years later, other studies demonstrated that myeloma, chronic lymphocytic leukemia and cancer stem cells become more susceptible to $\gamma \delta \mathrm{T}$ cells killing, when pretreated with N-BPs [63-67].

\section{Lipid Metabolism}

The primary metabolic resource of lipid metabolism is cholesterol, a fundamental component of membranes, because it regulates membrane fluidity and different receptormediated signal transduction pathways [68]. Many studies have shown a link between cholesterol homeostasis, cancer and immune response [69,70].

Cholesterol, LDL and HDL also influence the immunological activity of $\gamma \delta$ T cells in the tumor context. A first study [71] identified two lipidic-related ligands of the $\mathrm{V} \gamma 9 \mathrm{~V} \delta 2$ TCR on tumor targets: apolipoprotein A1 (Apo-A1) and ATP synthase/F1-ATPase (highaffinity apo A-I receptor) Apo-A1, abundant in HDL, are required for optimal activation of $\mathrm{V} \gamma 9 \mathrm{~V} \delta 2 \mathrm{~T}$ cells by tumors expressing F1-ATPase. Indeed, $\gamma \delta \mathrm{T}$ cell killing activity was impaired in the presence of Apo-A1-specific monoclonal antibody. Furthermore, the expression of the ATP synthase/F1-ATPase complex by tumor cells appears to influence the efficacy of killing of $\gamma \delta \mathrm{T}$ cells. Thus, the authors hypothesized that the $\mathrm{V} \gamma 9 \mathrm{~V} \delta 2 \mathrm{TCR}$, Apo$\mathrm{AI}$ and F1 make a tri-molecular complex required for tumor cell recognition [71]. A second study [72] investigated whether $\gamma \delta \mathrm{T}$ cell immune response could be influenced by LDL uptake. The authors of that study found that V $\delta 2 \mathrm{~T}$ cells expressed LDL receptor upon activation and the binding of LDL caused alterations of $\mathrm{V} \delta 2 \mathrm{~T}$ cells activation and functions. Notably, treatment of $\mathrm{V} \gamma 9 \mathrm{~V} \delta 2 \mathrm{~T}$ cells with LDL-cholesterol inhibited the expression of IFN- $\gamma$, NKG2D and DNAM-1.

Moreover, using an in vivo xenograft mouse model study, authors found that LDLcholesterol treatment did not affect the level of $\gamma \delta \mathrm{T}$ cells in blood or tumor tissue, but $\gamma \delta \mathrm{T}$ cells appear less effective against tumor cells and failed to control tumor growth [72]. Thus, LDL-cholesterol uptake appears to act as an inhibitor of the antitumor functions of $\mathrm{V} \gamma 9 \mathrm{~V} \delta 2$ T cells. Furthermore, upon other stress conditions, as during influenza infection, released host-derived lipids presented by lung infiltrating CD1d ${ }^{+} \mathrm{B}-1$ a cells, could activate $\gamma \delta \mathrm{T}$ cells for IL-17A induction via $\gamma \delta$ TCR-IRF4 pathway. Authors identified by single-cell RNA sequencing a subset of $\gamma \delta^{17}$ cells with TCR $\gamma \delta^{\text {hi }} \mathrm{CD} 3{ }^{\text {hi }} \mathrm{AQP} 3{ }^{\text {hi }} \mathrm{CXCR} 6{ }^{\text {hi }}$ phenotype, in both 
infected mice and patients with pneumonia [73]. Very recently, Lopes et al. [41] identified different metabolic programs of $\gamma \delta \mathrm{T}$ cell subsets, having a strong impact on their proand antitumoral activities in TME. They found that $\gamma \delta^{17}$ cells are enriched by the uptake of lipids, such as palmidrate and cholesterol. $\gamma \delta^{17}$ cells showed the ability to enhance tumor growth in tumor-bearing obese mice fed with the high-fat diet. The treatment with cholesterol increased their proliferation in vitro and promoted breast tumor growth upon adoptive cell transfer.

Conversely, in vitro supplementation of 10-fold higher glucose concentration augmented proliferation and cytotoxic activity of $\gamma \delta^{\mathrm{IFN}}$ cells against cancer cells, in addition to increased IFN- $\gamma$ production and T-bet expression. Not coincidentally, after in vivo adoptive cell transfer of glucose-boosted $\gamma \delta^{\mathrm{IFN}}$ cells, a significant reduction of breast tumor development was observed. The same effect on proliferation status was not observed for $\gamma \delta^{17}$ cells [41].

In light of these findings, there is an urgent need to study the involvement of lipid metabolism in the cytotoxic capacity of $\gamma \delta \mathrm{T}$ cells and, therefore, in their antitumor activity, to improve the efficacy of immunotherapies for those solid tumors against which the most modern clinical practices prove to be ineffective.

\section{Amino Acid Metabolism}

Within the TME, a competition is established between tumor cells and immune cells for amino acid requirements. Therefore, increased consumption of amino acids by tumor cells is necessary to sustain their constant growth and invasiveness [74], but at the same time, $\mathrm{T}$ cell activation requires amino acid uptake. Therefore, it is mediated by high expression of amino acid transporters, such as Large Neutral Amino Acids Transporter Small Subunit 1 (SLC7A5 also known as LAT1), Sodium-Dependent Neutral Amino Acid Transporter Type 2 (SLC1A5 also known as ASCT2) and Sodium- and Chloride-Dependent GABA Transporter 1 (SLC6A1 also known as GAT1) [75].

This duel was translated into compromised antitumor immune responses, inducing $\mathrm{T}$ cell anergy and affecting proliferation and effector activities [76].

The metabolism of L-arginine is one crucial regulator of immune responses and responsible for tumor progression. Multiple enzyme isoforms metabolize arginine: nitric oxide syntases (NOS1-3), arginases, glycine amidinotransferase and L-arginine decarboxylase [77]. NOS-mediated arginine metabolism gives rise to NO, which has strong immunomodulatory properties. NOS1 and NOS3 are constitutively expressed, instead, NOS2 is the inducible form [78] in response to pro-inflammatory cytokines such as IFN- $\gamma$, TNF- $\alpha$, and IL-1 $\beta$ and bacterial lipopolysaccharide.

In a study by Douguet et al., NOS2 drives the polarization of $\gamma \delta \mathrm{T}$ cells toward a protumoral phenotype within mouse and human primary melanoma, inducing the production of IL17 and favoring metastatic progression result the recruitment of myeloidderived suppressor cells (MDSC) [79]. The authors used mice transgenic for the Ret activated oncogene, which developed a spontaneous metastatic melanoma. In Ret mice knockout for NOS2, the correlation between the abundance of $\gamma \delta \mathrm{T}$ cells and MDSC was absent, compared to Ret mice, with impairing infiltration of $\gamma \delta^{17}$ cells. Moreover, the presence of NOS2 reduced the killing capacity of $\gamma \delta$ T cells against melanoma cell lines [79].

In a subsequent study, the authors confirmed that both cell populations are related to tumor progression [80]. Ret mice with a more aggressive melanoma showed a high infiltration of NOS2 expressing $\gamma \delta$ T cells and were enriched in pro-inflammatory cytokines IL-1 $\beta$ and IL-6. Neutralization of these pro-inflammatory cytokines caused a reduction of the NOS2 enzyme produced by $\gamma \delta$ T cells and a concomitant reduction of the tumoral aggressiveness, thus confirming an association between the expression of the enzyme by $\gamma \delta$ $\mathrm{T}$ cells and tumor progression. In addition, in Ret mice with vitiligo the level of $\gamma \delta \mathrm{T}$ cells and MDSC proportionally decreased, as confirmed by confocal microscope images [80]. Hence, these findings suggest a crucial connection between IL17, $\gamma \delta \mathrm{T}$ cells and MDSC orchestrated by NOS2. 
Finally, there is evidence that the presence of NOS2 also influences the metabolism of $\gamma \delta$ T cells. NOS2-deficient mice showed a low abundance of $\gamma \delta$ T cells in lymph nodes and a reduced capacity to produce IL-2. In addition, NOS2 neutralization inhibited $\gamma \delta \mathrm{T}$ cell proliferation and glycolysis, which was reversed by adding exogenous IL-2 [81].

Among other important amino acids, tryptophan is required for the survival and activation of $\mathrm{T}$ cells [82]. Its catabolism generates several metabolites (e.g., kynurenine, kynurenic acid, 3-hydroxy-kynurenine, and 3-hydroxy-anthranilic acid) released in the extracellular medium and are potentially toxic for immune cells. In particular, the kynurenines are overabundant in tumor cells that overexpress the enzymes indoleamine2,3-dioxygenase (IDO) and tryptophan 2,3-dioxygenase, responsible of first reaction in the kynurenine pathway [83]. Tryptophan starvation and kynurenines abundance have been shown to exert immunoregulatory properties, such as hindering activation and proliferation of immune cells [84]. In the study by Jonescheit et al. [85], treatment with recombinant kynurenine decreased the cytotoxic capacity of $\mathrm{V} \gamma 9 \mathrm{~V} \delta 2 \mathrm{~T}$ lymphocytes towards ductal pancreatic adenocarcinoma cells. IDO inhibitors, 1-methyl-levo-trypthophan and 1-methyldextro-tryptophan improved V $\gamma 9 \mathrm{~V} \delta 2 \mathrm{~T}$ lymphocyte cytotoxicity against pancreatic ductal adenocarcinoma (Panc89 and PancTu-I respectively) cell lines, after stimulation with bromohydrin diphosphate or in the presence of tribody [(HER2) $2 \times \mathrm{V} \gamma 9$ ] [85].

\section{Hypoxia and Metabolism}

Tumors are characterized by the development of two types of hypoxia: chronic and cycling. Chronic hypoxia results from a persistent lack of oxygenation due to the inability of blood vessels to keep up with the growth rate of cancer cells, thus increasing the distance $(>70 \mu \mathrm{m})$ between cells and blood vessels. Instead, cycling hypoxia, owing to unorganized vasculature, switches from episodes of oxygen reduction to re-oxygenation events [86].

Hypoxia-inducible factor $1 \alpha(\mathrm{HIF}-1 \alpha)$ is the pivotal transcription factor of response to hypoxia and a key regulator of many genes that drive both types of hypoxia-triggered cellular mechanisms, such as cancer development and invasion and immunosuppression [87]. To fix insufficient oxygen supply, HIF-1 $\alpha$ regulates the signaling of angiogenesis pathways and promotes vascularization of tumors, increasing the expression of proangiogenic factors such as vascular endothelial growth factor A, platelet-derived growth factor subunit A, transforming growth factor- $\beta$ and angiopoietin-like 4 [88,89]. Solid tumors include hypoxic regions adjacent to normoxic areas that show significantly low $\left[\mathrm{pO}_{2}\right]$ concentrations ( $<10 \mathrm{mmHg}$ ), compared to normal vascularized tissues [90]. Thus, hypoxia represents a negative prognostic factor and correlates to aggressiveness, metastatic progression and therapeutic resistance of tumors, as described in several reviews [91-93]. Indeed, HIF$1 \alpha$ regulates the expression of specific genes involved in the invasion, as fibronectin 1 , lysyl oxidase-like 2, urokinase plasminogen activator receptor, epithelial-mesenchymal transition-associated transcription factors ZEB, SNAIL and TWIST [87].

Not coincidentally, intratumoral hypoxia supports immune evasion and cancer progression, inducing metabolic changes within TME. It underlies acidosis and high concentrations of lactate, adenosine and ammonium in the extracellular medium, in addition to nutrient deprivation and increase of heat shock protein expression [94].

On the one hand, these adaptations allow tumor cells to survive and proliferate in hypoxic TME. On the other hand, they impact anti-tumor immune response, resulting in decreased proliferation and effector functions of cytotoxic CD8 ${ }^{+} \mathrm{T}$ cells, $\mathrm{CD} 4^{+}$helper T cells, NK cells, M1 macrophages and dendritic cells, and support the recruitment of immunosuppressive cells, such as MDSC, M2 macrophages and $\mathrm{T}_{\text {reg }}$ cells $[95,96]$. At present, the knowledge about the influence of hypoxia on $\gamma \delta$ T cells functions in TME is still controversial [97]. Hereafter, we comment on those few studies that illustrate this controversy.

A first study [98] investigated how hypoxia $\left(1 \% \mathrm{O}_{2}\right)$ impacts the effector functions of $\gamma \delta \mathrm{T}$ cells in advanced oral cancer patients (III stage and IV stage). Expression of HIF1- $\alpha$ was increased in infiltrating $\mathrm{V} \delta 2^{+} \mathrm{T}$ cells compared to $\mathrm{CD}^{+}$and $\mathrm{CD}^{+} \mathrm{T}$ cells. However, upon TCR stimulation, the expansion, proliferation and activation status of circulating 
$\gamma \delta \mathrm{T}$ cells, purified from healthy donors, were not hindered under hypoxic conditions. Moreover, after $24 \mathrm{~h}$ of stimulation and under either hypoxia or normoxia $\left(21 \% \mathrm{O}_{2}\right), \gamma \delta \mathrm{T}$ cells secreted similar levels of IFN- $\gamma$, TNF- $\alpha$ and IL-6. However, when exposed to hypoxia, $\gamma \delta \mathrm{T}$ cells, expanded from healthy donors and oral cancer patients, significantly reduced their cytotoxic activity against N-BP-treated oral cancer cell lines compared to normoxia.

Further, this ability was reduced when tumor target cells were exposed themselves to hypoxia. Thus, hypoxia compromised anti-tumor cytotoxicity of $\gamma \delta \mathrm{T}$ cells due to a reduction of calcium efflux and CD107a expression, which are responsible for regulating their effector functions. In addition, the authors assessed the impact of hypoxia on the differentiation of $\gamma \delta \mathrm{T}$ cells. Under hypoxic conditions, $\gamma \delta \mathrm{T}$ cells differentiated towards IL17A-producing $\gamma \delta \mathrm{T}$ cells, showing elevated ROR $\gamma \mathrm{t}$ expression. Consistent with these results, $\gamma \delta^{17}$ cells were increased among tumor-infiltrating lymphocytes in advanced oral cancer patients [98].

Park et al. showed that $\gamma \delta$ T cells in the glioma TME express high levels of HIF- $1 \alpha$ and Bax but reduced cytotoxic activity [99]. As brain tumors ran out of a lot of oxygen compared to other cancers and took it away from TILs, the authors speculated that inhibiting hypoxia could restore the ability of $\gamma \delta$ T cells to kill tumor cells. In particular, hypoxia-mediated activation of the cyclic AMP-PKA signaling pathway in $\gamma \delta$ T cells reduced NKG2A receptor expression, thereby abolishing their cytotoxicity. As previously demonstrated, upon metformin treatment, the oxygen uptake by tumor cells was reduced and more oxygen was available for TILs. Accordingly, following metformin treatment, antitumor $\gamma \delta$ T cells were restored, given by NKG2A and CD107a upregulation, granzyme B and IFN- $\gamma$ production, and acquired the ability to resist apoptosis [100]. Thus, the treatment of ex vivo expanded human $\gamma \delta \mathrm{T}$ cells with metformin or HIF- $1 \alpha$ inhibitor showed roughly $75 \%$ tumor-free survival in the glioma xenograft model [99]. In their study to evaluate the effects of hypoxia on cytotoxic functions of $\gamma \delta \mathrm{T}$ cells, Siegers et al. established in vitro co-cultures between $\gamma \delta \mathrm{T}$ cells and breast cancer cell lines under hypoxic condition. When $\gamma \delta \mathrm{T}$ cells were pre-incubated for $48 \mathrm{~h}$ in hypoxia, they exerted enhanced cytotoxicity against breast cancer cell lines, but breast tumor cell lines pre-cultured in hypoxia became resistant to $\gamma \delta \mathrm{T}$ cells killing due to MICA/B shedding by breast cancer cells [101].

Finally, in another recent paper, hypoxia attenuated antitumor effector functions of $\gamma \delta$ T cells, enhanced by oral squamous cell carcinoma-derived exosomes. This effect was related to the hypoxia-mediated suppressive effect of MDSCs on $\gamma \delta \mathrm{T}$ cells through a $\mathrm{miR}-21 / \mathrm{PTEN} / \mathrm{PD}-\mathrm{L} 1$ regulation axis [102].

\section{COX-2 and Prostaglandins}

Tumors often overexpress the cyclooxygenase $2(\mathrm{COX}-2)$ enzyme that catalyzes the metabolism of arachidonic acid to prostanoids, such as prostaglandins and thromboxanes [103].

Prostaglandin E2 (PGE2) binds four G-protein-coupled EP receptors (EP1-EP4) to improve tumor cell growth and survival, promote angiogenesis and induce metastatic cascade [104]. Thus, it actively contributes to establishing an immunosuppressive milieu playing a dual role: on one hand, PGE2 inhibits macrophages, neutrophils and Th1, NK and cytotoxic T cells; on the other hand, it promotes the activities of suppressive immune cells, such as $\mathrm{T}_{\text {reg, }}$, Th2, Th17 and MDSC [105].

In COX-2-expressing pancreatic ductal adenocarcinoma, increased levels of PGE2 induced resistance against $\gamma \delta \mathrm{T}$ cell cytotoxicity, which was restored by the co-treatment with COX-2 inhibitor DuP697 and tribody [(Her2) $2 \times$ V $\gamma 9$ ] [106]. Furthermore, PGE2-induced inhibition is mediated through activation of protein kinase A type I and interlopes with the cytotoxic receptors of $\gamma \delta$ T cells (CD16, NKG2D and TCR V $\gamma 9$ V 22$)$ [107]. Not by chance, the crucial role of PGE2 was confirmed in experiments assessing the immunosuppressive activity of mesenchymal stem cells against pAg-activated $\mathrm{V} \gamma 9 \mathrm{~V} \delta 2 \mathrm{~T}$ cells [108]. The release of inflammatory cytokines, such as IFN- $\gamma$ and TNF- $\alpha$, by $\gamma \delta$ T cells induced higher expression of COX-2 enzyme in mesenchymal stem cells with a consequent PGE2 production. 
In turn, PGE2 bound to G-coupled EP2 and EP4 receptors expressed on $\gamma \delta \mathrm{T}$ cells and increased cyclic adenosine monophosphate levels via adenylate cyclase activation. Thus, mesenchymal stem cells suppressed proliferation, cytokine production and cytotoxic ability of $\gamma \delta \mathrm{T}$ cells with negative feedback [108].

\section{Conclusions}

Since our and other authors' studies show that the TME alters the functions of $\gamma \delta$ $\mathrm{T}$ cells $[37,38]$, there is a need for more in-depth studies to define the molecules and the metabolic pathways responsible. In addition, these studies should answer some fundamental questions: (1) Do $\gamma \delta \mathrm{T}$ cells with pro- and antitumor activities have a distinct metabolic pattern in different types of cancer? (2) Can the TME contain specific metabolic biomarkers which orchestrate selective programs in $\gamma \delta$ T cells? (3) More generally, do particular metabolites in the TME modify innate and adaptive immune responses? Overall, these studies should provide comprehensive information, which should then be exploited to develop novel $\gamma \delta$ T cell-based therapeutic strategies [109] (Figure 3).

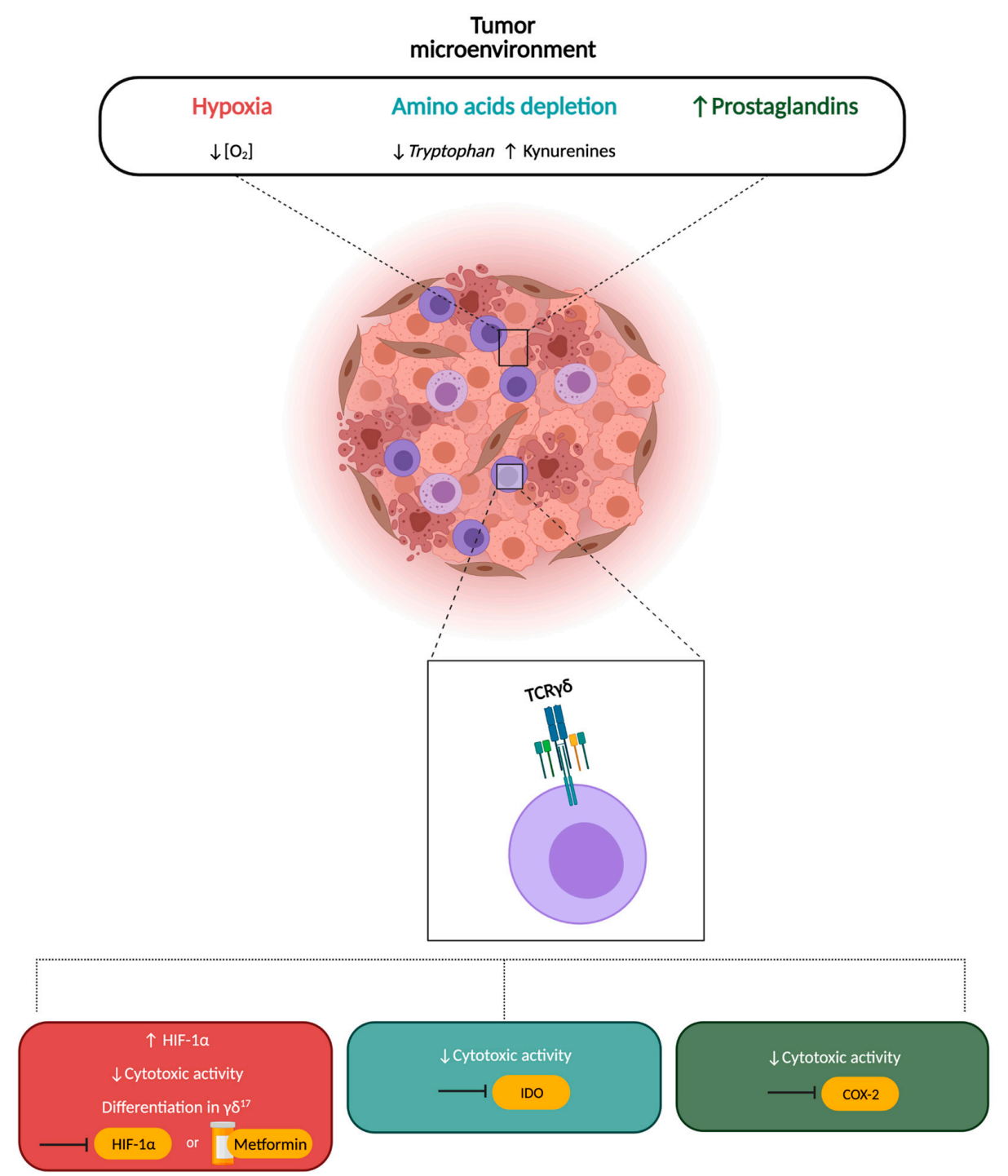

Figure 3. Strategies targeting metabolic alterations in the TME to improve $\gamma \delta \mathrm{T}$ cell effector functions. 
The competition for crucial nutrients, the accumulation of toxic molecules and a hypoxic environment hamper anti-tumor immune responses played by $\gamma \delta \mathrm{T}$ cells, impairing their cytotoxic activity or inducing their differentiation into $\gamma \delta^{17}$ with protumor functions. Conversely, manipulating tumor metabolism with specific inhibitors of HIF-1 $\alpha$, IDO or COX-2 or with the use of metformin inhibits these metabolic pathways and restores immune cells response. Abbreviations: $\gamma \delta^{17}$, IL17-producing $\gamma \delta$ T cells; HIF-1 $\alpha$, hypoxia-inducible factor 1-alpha; IDO, indoleamine-pyrrole 2,3-dioxygenase; COX-2, cyclooxygenase isoenzyme-2. Down arrow: low, up arrow: high.

Author Contributions: All authors contributed to writing the manuscript. F.D. and S.M. were responsible for the final editing. All authors have read and agreed to the published version of the manuscript.

Funding: This research was supported by funds from the Ministry of Education and Research (PRIN 2017-2017ALPCM to SM and PRIN 2017-2017M8YMR8_001 to FD).

Institutional Review Board Statement: Not applicable.

Informed Consent Statement: Not applicable.

Data Availability Statement: Not applicable.

Acknowledgments: Figures were created using Biorender.com.

Conflicts of Interest: The authors declare no conflict of interest.

\section{References}

1. Hanahan, D.; Weinberg, R.A. Hallmarks of cancer: The next generation. Cell 2011, 144, 46-74. [CrossRef]

2. Choi, S.Y.C.; Collins, C.C.; Gout, P.W.; Wang, Y. Cancer-generated lactic acid: A regulatory, immunosuppressive metabolite? J. Pathol. 2013, 230, 350-355. [CrossRef] [PubMed]

3. Brand, A.; Singer, K.; Koehl, G.E.; Kolitzus, M.; Schoenhammer, G.; Thiel, A.; Matos, C.; Bruss, C.; Klobuch, S.; Peter, K.; et al. LDHA-Associated Lactic Acid Production Blunts Tumor Immunosurveillance by T and NK Cells. Cell Metab. 2016, $24,657-671$. [CrossRef] [PubMed]

4. Yang, L.V. Tumor Microenvironment and Metabolism. Int. J. Mol. Sci. 2017, 18, 2729. [CrossRef] [PubMed]

5. Johnson, M.O.; Siska, P.J.; Contreras, D.C.; Rathmell, J.C. Nutrients and the microenvironment to feed a T cell army. Semin. Immunol. 2016, 28, 505-513. [CrossRef]

6. Nakagawa, Y.; Negishi, Y.; Shimizu, M.; Takahashi, M.; Ichikawa, M.; Takahashi, H. Effects of extracellular pH and hypoxia on the function and development of antigen-specific cytotoxic T lymphocytes. Immunol. Lett. 2015, 167, 72-86. [CrossRef]

7. Lacroix, R.; Rozeman, E.A.; Kreutz, M.; Renner, K.; Blank, C.U. Targeting tumor-associated acidity in cancer immunotherapy. Cancer Immunol. Immunother. 2018, 67, 1331-1348. [CrossRef]

8. Warburg, O.; Wind, F.; Negelein, E. The Metabolism of Tumors in the Body. J. Gen. Physiol. 1927, 8, 519-530. [CrossRef] [PubMed]

9. San-Millán, I.; Brooks, G.A. Reexamining cancer metabolism: Lactate production for carcinogenesis could be the purpose and explanation of the Warburg Effect. Carcinogenesis 2017, 38, 119-133. [CrossRef]

10. Harmon, C.; O'Farrelly, C.; Robinson, M.W. The Immune Consequences of Lactate in the Tumor Microenvironment. In Tumor Microenvironment: Molecular Player_Part A; Birbrair, A., Ed.; Springer International Publishing: Cham, Switzerland, 2020 ; pp. 113-124.

11. Xia, L.; Oyang, L.; Lin, J.; Tan, S.; Han, Y.; Wu, N.; Yi, P.; Tang, L.; Pan, Q.; Rao, S.; et al. The cancer metabolic reprogramming and immune response. Mol. Cancer 2021, 20,1-21. [CrossRef]

12. Picarda, E.; Ren, X.; Zang, X. Tumor Cholesterol Up, T Cells Down. Cell Metab. 2019, 30, 12-13. [CrossRef] [PubMed]

13. Mendler, A.N.; Hu, B.; Prinz, P.U.; Kreutz, M.; Gottfried, E.; Noessner, E. Tumor lactic acidosis suppresses CTL function by inhibition of p38 and JNK/c-Jun activation. Int. J. Cancer 2012, 131, 633-640. [CrossRef] [PubMed]

14. Angelin, A.; Gil-De-Gómez, L.; Dahiya, S.; Jiao, J.; Guo, L.; Levine, M.H.; Wang, Z.; Quinn, W.J.; Kopinski, P.K.; Wang, L.; et al. Foxp3 Reprograms T Cell Metabolism to Function in Low-Glucose, High-Lactate Environments. Cell Metab. 2017, 25, 1282-1293.e7. [CrossRef] [PubMed]

15. Xie, D.; Zhu, S.; Bai, L. Lactic acid in tumor microenvironments causes dysfunction of NKT cells by interfering with mTOR signaling. Sci. China Life Sci. 2016, 59, 1290-1296. [CrossRef]

16. Geltink, R.K.; Kyle, R.L.; Pearce, E.L. Unraveling the Complex Interplay Between T Cell Metabolism and Function. Annu. Rev. Immunol. 2018, 36, 461-488. [CrossRef]

17. Rivera, G.O.R.; Knochelmann, H.M.; Dwyer, C.J.; Smith, A.S.; Wyatt, M.M.; Rivera-Reyes, A.M.; Thaxton, J.E.; Paulos, C.M. Fundamentals of T Cell Metabolism and Strategies to Enhance Cancer Immunotherapy. Front. Immunol. 2021, 12, 5242. [CrossRef]

18. Meraviglia, S.; Lo Presti, E.; Dieli, F.; Stassi, G. $\gamma \delta$ T cell-based anticancer immunotherapy: Progress and possibilities. Immunotherapy 2015, 7, 949-951. [CrossRef]

19. Hoeres, T.; Smetak, M.; Pretscher, D.; Wilhelm, M. Improving the Efficiency of V $\gamma 9$ V $\delta 2$ T-Cell Immunotherapy in Cancer. Front. Immunol. 2018, 9, 800. [CrossRef] 
20. Calcinotto, A.; Filipazzi, P.; Grioni, M.; Iero, M.; De Milito, A.; Ricupito, A.; Cova, A.; Canese, R.; Jachetti, E.; Rossetti, M.; et al. Modulation of Microenvironment Acidity Reverses Anergy in Human and Murine Tumor-Infiltrating T Lymphocytes. Cancer Res. 2012, 72, 2746-2756. [CrossRef]

21. Silva-Santos, B.; Serre, K.; Norell, H. $\gamma \delta$ T cells in cancer. Nat. Rev. Immunol. 2015, 15, 683-691. [CrossRef]

22. Chitadze, G.; Oberg, H.H.; Wesch, D.; Kabelitz, D. The Ambiguous Role of $\gamma \delta$ T Lymphocytes in Antitumor Immunity. Trends Immunol. 2017, 38, 668-678. [CrossRef]

23. Wu, P.; Wu, D.; Ni, C.; Ye, J.; Chen, W.; Hu, G.; Wang, Z.; Wang, C.; Zhang, Z.; Xia, W.; et al. $\gamma \delta T 17$ Cells Promote the Accumulation and Expansion of Myeloid-Derived Suppressor Cells in Human Colorectal Cancer. Immunity 2014, 40, 785-800. [CrossRef] [PubMed]

24. Ma, S.; Cheng, Q.; Cai, Y.; Gong, H.; Wu, Y.; Yu, X.; Shi, L.; Wu, D.; Dong, C.; Liu, H. IL-17A produced by $\gamma \delta \mathrm{T}$ cells promotes tumor growth in hepatocellular carcinoma. Cancer Res. 2014, 74, 1969-1982. [CrossRef] [PubMed]

25. Lo Presti, E.; Di Mitri, R.; Pizzolato, G.; Mocciaro, F.; Dieli, F.; Meraviglia, S. $\gamma \delta$ cells and tumor microenvironment: A helpful or a dangerous liason? J. Leukoc. Biol. 2018, 103, 485-492. [CrossRef] [PubMed]

26. Vantourout, P.; Hayday, A. Six-of-the-best: Unique contributions of $\gamma \delta$ T cells to immunology. Nat. Rev. Immunol. 2013, 13, 88-100. [CrossRef] [PubMed]

27. Lo Presti, E.; Corsale, A.M.; Dieli, F.; Meraviglia, S. $\gamma \delta$ cell-based immunotherapy for cancer. Expert Opin. Biol. Ther. 2019, 19, 887-895. [CrossRef]

28. Yang, Y.; Xu, C.; Wu, D.; Wang, Z.; Wu, P.; Li, L.; Huang, J.; Qiu, F. $\gamma \delta$ T Cells: Crosstalk Between Microbiota, Chronic Inflammation, and Colorectal Cancer. Front. Immunol. 2018, 9, 1483. [CrossRef]

29. Lo Presti, E.; Dieli, F.; Meraviglia, S. Tumor-Infiltrating $\gamma \delta$ T Lymphocytes: Pathogenic Role, Clinical Significance, and Differential Programing in the Tumor Microenvironment. Front. Immunol. 2014, 5, 607. [CrossRef]

30. Dieli, F.; Poccia, F.; Lipp, M.; Sireci, G.; Caccamo, N.; Di Sano, C.; Salerno, A. Differentiation of effector/memory Vdelta2 T cells and migratory routes in lymph nodes or inflammatory sites. J. Exp. Med. 2003, 198, 391-397. [CrossRef] [PubMed]

31. Caccamo, N.; Meraviglia, S.; Ferlazzo, V.; Angelini, D.; Borsellino, G.; Poccia, F.; Battistini, L.; Dieli, F.; Salerno, A. Differential requirements for antigen or homeostatic cytokines for proliferation and differentiation of human $\mathrm{V} \gamma \mathrm{V} \delta 2 \mathrm{naive}$, memory and effector T cell subsets. Eur. J. Immunol. 2005, 35, 1764-1772. [CrossRef]

32. Wesch, D.; Glatzel, A.; Kabelitz, D. Differentiation of resting human peripheral blood gamma delta T cells toward Th1-or Th2-phenotype. Cell Immunol. 2001, 212, 110-117. [CrossRef] [PubMed]

33. Queck, A.; Rueschenbaum, S.; Kubesch, A.; Cai, C.; Zeuzem, S.; Weigert, A.; Brüne, B.; Nour-Eldin, N.E.A.; Gruber-Rouh, T.; Vogl, T.; et al. Cytokine requirements for the differentiation and expansion of IL-17A- and IL-22-producing human Vgamma2Vdelta2 T cells. J. Immunol. 2010, 184, 7268-7280.

34. Fenoglio, D.; Poggi, A.; Catellani, S.; Battaglia, F.; Ferrera, A.; Setti, M.; Murdaca, G.; Zocchi, M.R. Vdelta1 T lymphocytes producing IFN-gamma and IL-17 are expanded in HIV-1-infected patients and respond to Candida albicans. Blood 2009, 113, 6611-6618. [CrossRef] [PubMed]

35. Bansal, R.R.; Mackay, C.R.; Moser, B.; Eberl, M. IL-21 enhances the potential of human $\gamma \delta$ T cells to provide B-cell help. Eur. J. Immunol. 2012, 42, 110-119. [CrossRef]

36. Casetti, R.; Agrati, C.; Wallace, M.; Sacchi, A.; Martini, F.; Martino, A.; Rinaldi, A.; Malkovsky, M. Cutting edge: TGF-beta1 and IL-15 Induce FOXP3+ gammadelta regulatory T cells in the presence of antigen stimulation. J. Immunol. 2009, 183, 3574-3577. [CrossRef]

37. Meraviglia, S.; Lo Presti, E.; Tosolini, M.; La Mendola, C.; Orlando, V.; Todaro, M.; Catalano, V.; Stassi, G.; Cicero, G.; Vieni, S.; et al. Distinctive features of tumor-infiltrating $\gamma \delta$ T lymphocytes in human colorectal cancer. Oncoimmunology 2017, 6, e1347742. [CrossRef] [PubMed]

38. Lo Presti, E.; Toia, F.; Oieni, S.; Buccheri, S.; Turdo, A.; Mangiapane, L.R.; Campisi, G.; Caputo, V.; Todaro, M.; Stassi, G.; et al. Squamous Cell Tumors Recruit $\gamma \delta$ T Cells Producing either IL17 or IFN $\gamma$ Depending on the Tumor Stage. Cancer Immunol. Res. 2017, 5, 397-407. [CrossRef]

39. Balyan, R.; Gautam, N.; Gascoigne, N. The Ups and Downs of Metabolism during the Lifespan of a T Cell. Int. J. Mol. Sci. 2020, 21, 7972. [CrossRef]

40. Argüello, R.J.; Combes, A.J.; Char, R.; Gigan, J.-P.; Baaziz, A.I.; Bousiquot, E.; Camosseto, V.; Samad, B.; Tsui, J.; Yan, P.; et al. SCENITH: A Flow Cytometry-Based Method to Functionally Profile Energy Metabolism with Single-Cell Resolution. Cell Metab. 2020, 32, 1063-1075.e7. [CrossRef] [PubMed]

41. Lopes, N.; McIntyre, C.; Martin, S.; Raverdeau, M.; Sumaria, N.; Kohlgruber, A.C.; Fiala, G.J.; Agudelo, L.Z.; Dyck, L.; Kane, H.; et al. Distinct metabolic programs established in the thymus control effector functions of $\gamma \delta$ T cell subsets in tumor microenvironments. Nat. Immunol. 2021, 22, 179-192. [CrossRef]

42. Donnelly, R.P.; Loftus, R.M.; Keating, S.E.; Liou, K.T.; Biron, C.A.; Gardiner, C.M.; Finlay, D.K. mTORC1-Dependent Metabolic Reprogramming Is a Prerequisite for NK Cell Effector Function. J. Immunol. 2014, 193, 4477-4484. [CrossRef] [PubMed]

43. Cham, C.M.; Gajewski, T.F. Glucose availability regulates IFN-gamma production and p70S6 kinase activation in CD8+ effector T cells. J. Immunol. 2005, 174, 4670-4677. [CrossRef] 
44. Shin, B.; Benavides, G.A.; Geng, J.; Koralov, S.; Hu, H.; Darley-Usmar, V.M.; Harrington, L.E. Mitochondrial Oxidative Phosphorylation Regulates the Fate Decision between Pathogenic Th17 and Regulatory T Cells. Cell Rep. 2020, 30, 1898-1909.e4. [CrossRef]

45. Groh, V.; Steinle, A.; Bauer, S.; Spies, T. Recognition of stress-induced MHC molecules by intestinal epithelial gammadelta T cells. Science 1998, 279, 1737-1740. [CrossRef]

46. Poggi, A.; Venturino, C.; Catellani, S.; Clavio, M.; Miglino, M.; Gobbi, M.; Steinle, A.; Ghia, P.; Stella, S.; Caligaris-Cappio, F.; et al Vdelta1 T lymphocytes from B-CLL patients recognize ULBP3 expressed on leukemic B cells and up-regulated by trans-retinoic acid. Cancer Res. 2004, 64, 9172-9179. [CrossRef]

47. Roelofs, A.J.; Jauhiainen, H.; Mönkkönen, H.; Rogers, M.J.; Mönkkönen, J.; Thompson, K. Peripheral blood monocytes are responsible for gammadelta $\mathrm{T}$ cell activation induced by zoledronic acid through accumulation of IPP/DMAPP. Br. J. Haematol. 2009, 144, 245-250. [CrossRef] [PubMed]

48. Constant, P.; Davodeau, F.; Peyrat, M.A.; Poquet, Y.; Puzo, G.; Bonneville, M.; Fourniè, J.J. Stimulation of human gamma delta T cells by nonpeptidic mycobacterial ligands. Science 1994, 264, 267-270. [CrossRef]

49. Tanaka, Y.; Morita, C.T.; Tanaka, Y.; Nieves, E.; Brenner, M.B.; Bloom, B.R. Natural and synthetic non-peptide antigens recognized by human gamma delta T cells. Nature 1995, 375, 155-158. [CrossRef] [PubMed]

50. Altincicek, B.; Moll, J.; Campos, N.; Foerster, G.; Beck, E.; Hoeffler, J.F.; Grosdemange-Billiard, C.; Rodrìguez-Concepciòn, M.; Rohmer, M.; Boronat, A.; et al. Cutting edge: Human gamma delta T cells are activated by intermediates of the 2-C-methyl-Derythritol 4-phosphate pathway of isoprenoid biosynthesis. J. Immunol. 2001, 166, 3655-3658. [CrossRef]

51. Gober, H.J.; Kistowska, M.; Angman, L.; Jenö, P.; Mori, L.; De Libero, G. Human T cell receptor gammadelta cells recognize endogenous mevalonate metabolites in tumor cells. J. Exp. Med. 2003, 197, 163-168. [CrossRef] [PubMed]

52. Freed-Pastor, W.A.; Mizuno, H.; Zhao, X.; Langerød, A.; Moon, S.H.; Rodriguez-Barrueco, R.; Barsotti, A.; Chicas, A.; Li, W.; Polotskaia, A.; et al. Mutant p53 disrupts mammary tissue architecture via the mevalonate pathway. Cell 2012, 148, 244-258. [CrossRef] [PubMed]

53. Bjarnadottir, O.; Romero, Q.; Bendahl, P.O.; Jirström, K.; Rydén, L.; Loman, N.; Uhlèn, M.; Johannesson, H.; Rose, C.; Grabau, D.; et al. Targeting HMG-CoA reductase with statins in a window-of-opportunity breast cancer trial. Breast Cancer Res. Treat. 2013, 138, 499-508. [CrossRef]

54. Vavassori, S.; Kumar, A.; Wan, G.S.; Ramanjaneyulu, G.S.; Cavallari, M.; El Daker, S.; Beddoe, T.; Theodossis, A.; Williams, N.K.; Gostick, E.; et al. Butyrophilin 3A1 binds phosphorylated antigens and stimulates human $\gamma \delta$ T cells. Nat. Immunol. 2013, 14, 908-916. [CrossRef] [PubMed]

55. Rigau, M.; Ostrouska, S.; Fulford, T.S.; Johnson, D.N.; Woods, K.; Ruan, Z.; McWilliam, H.E.G.; Hudson, C.; Tutuka, C.; Wheatley, A.K.; et al. Butyrophilin 2A1 is essential for phosphoantigen reactivity by $\gamma \delta \mathrm{T}$ cells. Science 2020, 367, 5516. [CrossRef]

56. Eberl, M. Antigen recognition by human $\gamma \delta$ T cells: One step closer to knowing. Immunol. Cell Biol. 2020, 98, 351-354. [CrossRef]

57. Karunakaran, M.M.; Willcox, C.R.; Salim, M.; Paletta, D.; Fichtner, A.S.; Noll, A.; Starick, L.; Nöhren, A.; Begley, C.R.; Berwick, K.A.; et al. Butyrophilin-2A1 Directly Binds Germline-Encoded Regions of the V $\gamma 9$ V $\delta 2$ TCR and Is Essential for Phosphoantigen Sensing. Immunity 2020, 52, 487-498.e6. [CrossRef]

58. Herrmann, T.; Fichtner, A.S.; Karunakaran, M.M. An Update on the Molecular Basis of Phosphoantigen Recognition by V $\gamma 9 \mathrm{~V} \delta 2 \mathrm{~T}$ Cells. Cells 2020, 9, 1433. [CrossRef]

59. Gruenbacher, G.; Thurnher, M. Mevalonate Metabolism in Immuno-Oncology. Front. Immunol. 2017, 8, 1714. [CrossRef] [PubMed]

60. Kuźnik, A.; Pazdzierniok-Holewa, A.; Jewula, P.; Kuźnik, N. Bisphosphonates-much more than only drugs for bone diseases. Eur. J. Pharmacol. 2019, 866, 172773. [CrossRef] [PubMed]

61. Rodriguez, J.B.; Falcone, B.N.; Szajnman, S.H. Approaches for Designing new Potent Inhibitors of Farnesyl Pyrophosphate Synthase. Expert Opin. Drug Discov. 2016, 11, 307-320. [CrossRef]

62. Li, J.; Herold, M.J.; Kimmel, B.; Müller, I.; Rincon-Orozco, B.; Kunzmann, V.; Herrmann, T. Reduced expression of the mevalonate pathway enzyme farnesyl pyrophosphate synthase unveils recognition of tumor cells by Vgamma9Vdelta2 T cells. J. Immunol. 2009, 182, 8118-8124. [CrossRef]

63. Coscia, M.; Vitale, C.; Peola, S.; Foglietta, M.; Rigoni, M.; Griggio, V.; Castella, B.; Angelini, D.; Chiaretti, S.; Riganti, C.; et al. Dysfunctional $\mathrm{V} \gamma 9 \mathrm{~V} \delta 2 \mathrm{~T}$ cells are negative prognosticators and markers of dysregulated mevalonate pathway activity in chronic lymphocytic leukemia cells. Blood 2012, 120, 3271-3279. [CrossRef] [PubMed]

64. Benzaïd, I.; Mönkkönen, H.; Stresing, V.; Bonnelye, E.; Green, J.; Mönkkönen, J.; Touraine, J.L.; Clèzardin, P. High phosphoantigen levels in bisphosphonate-treated human breast tumors promote Vgamma9Vdelta2 T-cell chemotaxis and cytotoxicity in vivo. Cancer Res. 2011, 71, 4562-4572. [CrossRef] [PubMed]

65. Nishio, N.; Fujita, M.; Tanaka, Y.; Maki, H.; Zhang, R.; Hirosawa, T.; Demachi-Okamura, A.; Uemura, Y.; Taguchi, O.; Takahashi, Y.; et al. Zoledronate Sensitizes Neuroblastoma-derived Tumor-initiating Cells to Cytolysis Mediated by Human $\gamma \delta \mathrm{T}$ Cells. J. Immunother. 2012, 35, 598-606. [CrossRef]

66. Todaro, M.; D'Asaro, M.; Caccamo, N.; Iovino, F.; Francipane, M.G.; Meraviglia, S.; Orlando, V.; La Mendola, C.; Gulotta, G.; Salerno, A.; et al. Efficient killing of human colon cancer stem cells by gammadelta T lymphocytes. J. Immunol. 2009, 182, 7287-7296. [CrossRef] [PubMed] 
67. Uchida, R.; Ashihara, E.; Sato, K.; Kimura, S.; Kuroda, J.; Takeuchi, M.; Kawata, E.; Taniguchi, K.; Okamoto, M.; Shimura, K. Gamma delta T cells kill myeloma cells by sensing mevalonate metabolites and ICAM-1 molecules on cell surface. Biochem. Biophys. Res. Commun. 2007, 354, 613-618. [CrossRef]

68. Feingold, K.R.; Anawalt, B.; Boyce, A.; Chrousos, G.; de Herder, W.W.; Dungan, K.; Grossmann, A.; Hershman, J.M.; Hofland, J.; Kaltsas, G.; et al. Introduction to Lipids and Lipoproteins. In Endotext; MDText.com, Inc.: South Dartmouth, MA, USA, 2000.

69. Hansson, G.K.; Hermansson, A. The immune system in atherosclerosis. Nat. Immunol. 2011, 12, 204-212. [CrossRef]

70. Kidani, Y.; Bensinger, S.J. Modulating Cholesterol Homeostasis to Build a Better T Cell. Cell Metab. 2016, 23, 963-964. [CrossRef] [PubMed]

71. Scotet, E.; Martinez, L.O.; Grant, E.; Barbaras, R.; Jenö, P.; Guiraud, M.; Monsarrat, B.; Saulquin, X.; Maillet, S.; Estève, J.P.; et al. Tumor recognition following Vgamma9Vdelta2 $\mathrm{T}$ cell receptor interactions with a surface F1-ATPase-related structure and apolipoprotein A-I. Immunity 2005, 22, 71-80. [CrossRef]

72. Rodrigues, N.V.; Correia, D.V.; Mensurado, S.; Nobrega-Pereira, S.; DeBarros, A.; Kyle-Cezar, F.; Tutt, A.; Hayday, A.; Norell, H.; Silva-Santos, B.; et al. Low-Density Lipoprotein Uptake Inhibits the Activation and Antitumor Functions of Human V $\gamma 9 \mathrm{~V} \delta 2 \mathrm{~T}$ Cells. Cancer Immunol. Res. 2018, 6, 448-457. [CrossRef]

73. Wang, X.; Lin, X.; Zheng, Z.; Lu, B.; Wang, J.; Tan, A.H.-M.; Zhao, M.; Loh, J.T.; Ng, S.W.; Chen, Q.; et al. Host-derived lipids orchestrate pulmonary $\gamma \delta \mathrm{T}$ cell response to provide early protection against influenza virus infection. Nat. Commun. 2021, 12, 1-19. [CrossRef]

74. Muhammad, N.; Lee, H.M.; Kim, J. Oncology Therapeutics Targeting the Metabolism of Amino Acids. Cells 2020, 9, 1904. [CrossRef]

75. RRen, W.; Liu, G.; Yin, J.; Tan, B.; Wu, G.; Bazer, F.W.; Peng, Y.; Yin, Y. Amino-acid transporters in T-cell activation and differentiation. Cell Death Dis. 2017, 8, e2655. [CrossRef]

76. Kelly, B.; Pearce, E.L. Amino Assets: How Amino Acids Support Immunity. Cell Metab. 2020, 32, 154-175. [CrossRef]

77. Caldwell, R.W.; Rodriguez, P.C.; Toque, H.A.; Narayanan, S.P. Arginase: A Multifaceted Enzyme Important in Health and Disease. Physiol. Rev. 2018, 98, 641-665. [CrossRef] [PubMed]

78. Brüne, B.; Courtial, N.; Dehne, N.; Syed, S.N.; Weigert, A. Macrophage NOS2 in Tumor Leukocytes. Antioxidants Redox Signal. 2017, 26, 1023-1043. [CrossRef]

79. Douguet, L.; Bod, L.; Lengagne, R.; Labarthe, L.; Kato, M.; Avril, M.-F.; Prévost-Blondel, A. Nitric oxide synthase 2 is involved in the pro-tumorigenic potential of $\gamma \delta 17 \mathrm{~T}$ cells in melanoma. Oncoimmunology 2016, 5, e1208878. [CrossRef]

80. Douguet, L.; Bod, L.; Labarthe, L.; Lengagne, R.; Kato, M.; Couillin, I.; Prèvost-Blondel, A. Inflammation drives nitric oxide synthase 2 expression by $\gamma \delta$ T cells and affects the balance between melanoma and vitiligo associated melanoma. Oncoimmunology 2018, 7, e1484979. [CrossRef]

81. Douguet, L.; Cherfils-Vicini, J.; Bod, L.; Lengagne, R.; Gilson, E.; Prévost-Blondel, A. Nitric Oxide Synthase 2 Improves Proliferation and Glycolysis of Peripheral $\gamma \delta$ T Cells. PLoS ONE 2016, 11, e0165639. [CrossRef] [PubMed]

82. Moffett, J.R.; Namboodiri, M.A. Tryptophan and the immune response. Immunol. Cell Biol. 2003, 81, 247-265. [CrossRef]

83. Mor, A.; Tankiewicz-Kwedlo, A.; Pawlak, D. Kynurenines as a Novel Target for the Treatment of Malignancies. Pharmaceuticals 2021, 14, 606. [CrossRef] [PubMed]

84. Zhai, L.; Bell, A.; Ladomersky, E.; Lauing, K.L.; Bollu, L.; Sosman, J.A.; Zhang, B.; Wu, J.D.; Miller, S.D.; Meeks, J.J.; et al. Immunosuppressive IDO in Cancer: Mechanisms of Action, Animal Models, and Targeting Strategies. Front. Immunol. 2020, 11, 1185. [CrossRef] [PubMed]

85. Jonescheit, H.; Oberg, H.; Gonnermann, D.; Hermes, M.; Sulaj, V.; Peters, C.; Kabelitz, D.; Wesh, D. Influence of Indoleamine-2,3Dioxygenase and Its Metabolite Kynurenine on $\gamma \delta$ T Cell Cytotoxicity against Ductal Pancreatic Adenocarcinoma Cells. Cells 2020, 9, 1140. [CrossRef] [PubMed]

86. Michiels, C.; Tellier, C.; Feron, O. Cycling hypoxia: A key feature of the tumor microenvironment. Biochim. Biophys. Acta (BBA)-Bioenerg. 2016, 1866, 76-86. [CrossRef] [PubMed]

87. Shi, R.; Liao, C.; Zhang, Q. Hypoxia-Driven Effects in Cancer: Characterization, Mechanisms, and Therapeutic Implications. Cells 2021, 10, 678. [CrossRef]

88. Lee, P.; Chandel, N.S.; Simon, M.C. Cellular adaptation to hypoxia through hypoxia inducible factors and beyond. Nat. Rev. Mol. Cell Biol. 2020, 21, 268-283. [CrossRef]

89. Krock, B.L.; Skuli, N.; Simon, M.C. Hypoxia-Induced Angiogenesis: Good and Evil. Genes Cancer 2011, 2, 1117-1133. [CrossRef] [PubMed]

90. Noman, M.Z.; Hasmim, M.; Lequeux, A.; Xiao, M.; Duhem, C.; Chouaib, S.; Berchem, G.; Janji, B. Improving Cancer Immunotherapy by Targeting the Hypoxic Tumor Microenvironment: New Opportunities and Challenges. Cells $2019,8,1083$. [CrossRef]

91. Vaupel, P.; Mayer, A. Hypoxia in cancer: Significance and impact on clinical outcome. Cancer Metastasis Rev. 2007, 26, 225-239. [CrossRef]

92. Walsh, J.C.; Lebedev, A.; Aten, E.; Madsen, K.; Marciano, L.; Kolb, H.C. The clinical importance of assessing tumor hypoxia: Relationship of tumor hypoxia to prognosis and therapeutic opportunities. Antioxid. Redox Signal. 2014, 21, 1516-1554. [CrossRef]

93. Muz, B.; de la Puente, P.; Azab, F.; Azab, A.K. The role of hypoxia in cancer progression, angiogenesis, metastasis, and resistance to therapy. Hypoxia 2015, 3, 83-92. [CrossRef] 
94. Multhoff, G.; Vaupel, P. Hypoxia Compromises Anti-Cancer Immune Responses. In Oxygen Transport to Tissue XLI; Springer International Publishing: Cham, Switzerland, 2020; pp. 131-143. [CrossRef]

95. Wang, B.; Zhao, Q.; Zhang, Y.; Liu, Z.; Zheng, Z.; Liu, S.; Meng, L.; Xin, Y.; Jiang, X. Targeting hypoxia in the tumor microenvironment: A potential strategy to improve cancer immunotherapy. J. Exp. Clin. Cancer Res. 2021, 40, 1-16. [CrossRef]

96. Vito, A.; El-Sayes, N.; Mossman, K. Hypoxia-Driven Immune Escape in the Tumor Microenvironment. Cells $2020,9,992$. [CrossRef]

97. Yan, J. Antitumor $\gamma \delta$ T cells need oxygen to function. Nat. Immunol. 2021, 22, 268-269. [CrossRef]

98. Sureshbabu, S.K.; Chaukar, D.; Chiplunkar, S.V. Hypoxia regulates the differentiation and anti-tumor effector functions of $\gamma \delta \mathrm{T}$ cells in oral cancer. Clin. Exp. Immunol. 2020, 201, 40-57. [CrossRef]

99. Park, J.H.; Kim, H.; Kim, C.W.; Kim, H.C.; Jung, Y.; Lee, H.; Lee, Y.; Ju, Y.S.; Oh, J.E.; Park, S.; et al. Tumor hypoxia represses $\gamma \delta ~ T$ cell-mediated antitumor immunity against brain tumors. Nat. Immunol. 2021, 22, 336-346. [CrossRef]

100. Chen, G.G.; Woo, P.Y.; Ng, S.C.; Wong, G.K.; Chan, D.T.; van Hasselt, C.A.; Tong, M.C.; Poon, W.S. Impact of metformin on immunological markers: Implication in its anti-tumor mechanism. Pharmacol. Ther. 2020, 213, 107585. [CrossRef]

101. Siegers, G.M.; Dutta, I.; Lai, R.; Postovit, L.M. Functional Plasticity of Gamma Delta T Cells and Breast Tumor Targets in Hypoxia. Front. Immunol. 2018, 9, 1367. [CrossRef] [PubMed]

102. Li, L.; Cao, B.; Liang, X.; Lu, S.; Luo, H.; Wang, Z.; Wang, S.; Jiang, J.; Lang, J.; Zhu, G. Microenvironmental oxygen pressure orchestrates an anti- and pro-tumoral $\gamma \delta$ T cell equilibrium via tumor-derived exosomes. Oncogene 2018, 38, 2830-2843. [CrossRef] [PubMed]

103. Hashemi Goradel, N.; Najafi, M.; Salehi, E.; Farhood, B.; Mortezaee, K. Cyclooxygenase-2 in cancer: A review. J. Cell. Physiol. 2019, 234, 5683-5699. [CrossRef] [PubMed]

104. Finetti, F.; Travelli, C.; Ercoli, J.; Colombo, G.; Buoso, E.; Trabalzini, L. Prostaglandin E2 and Cancer: Insight into Tumor Progression and Immunity. Biology 2020, 9, 434. [CrossRef] [PubMed]

105. Kalinski, P. Regulation of Immune Responses by Prostaglandin E2. J. Immunol. 2011, 188, 21-28. [CrossRef] [PubMed]

106. Gonnermann, D.; Oberg, H.-H.; Kellner, C.; Peipp, M.; Sebens, S.; Kabelitz, D.; Wesch, D. Resistance of cyclooxygenase-2 expressing pancreatic ductal adenocarcinoma cells against $\gamma \delta$ T cell cytotoxicity. OncoImmunology 2015, 4, e988460. [CrossRef] [PubMed]

107. Martinet, L.; Jean, C.; Dietrich, G.; Fourniè, J.J.; Poupot, R. PGE2 inhibits natural killer and $\gamma \delta$ T cell cytotoxicity triggered by NKR and TCR through a cAMP-mediated PKA type I-dependent signaling. Biochem. Pharmacol. 2010, 80, 838-845. [CrossRef]

108. Martinet, L.; Fleury-Cappellesso, S.; Gadelorge, M.; Dietrich, G.; Bourin, P.; Fourniè, J.J.; Poupot, R. A regulatory cross-talk between V $\gamma 9 \mathrm{~V} \delta 2 \mathrm{~T}$ lymphocytes and mesenchymal stem cells. Biochem. Pharmacol. 2009, 39, 752-762. [CrossRef]

109. Afonso, J.; Santos, L.L.; Longatto-Filho, A.; Baltazar, F. Competitive glucose metabolism as a target to boost bladder cancer immunotherapy. Nat. Rev. Urol. 2020, 17, 77-106. [CrossRef] [PubMed] 